\title{
Seasonality of larvae of Brachyura and Anomura (Crustacea Decapoda) in the Beagle Channel, Argentina*
}

\author{
GUSTAVO A. LOVRICH \\ Consejo Nacional de Investigaciones Científicas y Técnicas (CONICET). Centro Austral de Investigaciones Científicas \\ (CADIC), CC 92 - (9410) Ushuaia, Tierra del Fuego, Argentina. E-mail: lovrich@satlink.com
}

\begin{abstract}
SUMMARY: This is the first study in the Beagle Channel that reports the larval seasonal distribution, abundance and duration of the larval stages of Anomura and Brachyura, on the basis of a fortnightly sampling programme. An identification key to the specific level of zoeal stages is included. Between September 1987 and March 1989, 304 plankton samples were taken by means of oblique hauls from the bottom to the sea-surface. Eighty-five percent of the samples were taken shallower than $60 \mathrm{~m}$ depth. Decapod larvae occurred only in spring and summer. All but two taxa showed a single cohort of larvae which emerge at the beginning of the spring. A second cohort of Munida spp. and Halicarcinus planatus also occurred during summer. The most abundant taxa were Munida spp. (312 larvae $\left.\cdot 10 \mathrm{~m}^{-3}\right)$, Peltarion spinosulum $\left(288\right.$ larvae $\left.\cdot 10 \mathrm{~m}^{-3}\right)$, H. planatus $\left(143\right.$ larvae $\cdot 10 \mathrm{~m}^{-3}$ ) and Pagurus spp. (79 larvae $\cdot 10 \mathrm{~m}^{-3}$ ), which represented $97 \%$ of the total larvae collected. Larvae of Pinnotheridae, Eurypodius latreillii, Libidoclaea granaria, and Paralomis granulosa were about an order of magnitude less abundant. Relative abundances of larvae correspond to relative abundances of the respective benthic stages. The absence of certain larval stages or of certain species (Acanthocyclus albatrossis and Lithodes santolla) probably indicates their differential distribution within the Beagle Channel. Particularly, lithodid larvae may have benthic or epibenthic habits.
\end{abstract}

Key words: Crab, southwestern Atlantic, southeastern Pacific, Subantarctic, development, antiboreal.

RESUMEN: Estacionalidad de larvas de Brachyura y ANOMURa (CRustacea DeCapoda) en el Canal del Beagle, ARGENTINA. - En este artículo se presenta la distribución estacional, abundancia y duración de los estadios larvales de los Anomura y Brachyura presentes en el plancton del Canal del Beagle, Argentina, sobre la base de muestreos quincenales. Se incluye además una clave para la identificación de los estadios zoea al nivel taxonómico de especie. Entre septiembre de 1987 y marzo de 1989, se tomaron 304 muestras de plancton, la mayoría provenientes de lances oblícuos desde el fondo hasta la superficie del mar. El $85 \%$ de las muestras se tomaron a $<60 \mathrm{~m}$ de profundidad. Las larvas estuvieron presentes sólo en primavera y en verano. Todos los taxa excepto dos presentaron una cohorte que provino de la eclosión de los huevos que ocurrió a comienzos de la primavera. Munida spp. y Halicarcinus planatus presentaron también una segunda cohorte durante el verano. Los taxa más abundantes fueron Munida spp. (312 larvas $\left.\cdot 10 \mathrm{~m}^{-3}\right)$, Peltarion spinosulum (288 larvas $\cdot 10 \mathrm{~m}^{-3}$ ), H. planatus (143 larvas $\cdot 10 \mathrm{~m}^{-3}$ ) y Pagurus spp. (79 larvas $\cdot 10 \mathrm{~m}^{-3}$ ), y representaron el $97 \%$ de las larvas recolectadas. Las larvas de Pinnotheridae, Eurypodius latreillii, Libidoclaea granaria, y Paralomis granulosa fueron aproximadamente un orden de magnitud menos abundantes que las anteriores. La abundancia relativa de las larvas se corresponde aproximadamente con la abundancia relativa de los estadios bentónicos de los respectivos taxones. La ausencia de ciertos estadios larvales o de ciertas especies (Acanthocyclus albatrossis y Lithodes santolla) podría ser debida a una distribución diferencial de las larvas de anomuros y braquiuros dentro del Canal del Beagle. En particular, debido a la ausencia de las larvas de Lithodidae en el plancton se plantea la hipótesis de que sean bentónicas o epibentónicas.

Palabras clave: Cangrejo, Atlántico sudoccidental, Pacífico sudoriental, Subantártida, desarrollo, antiboreal.

*Accepted July 17, 1998. 


\section{INTRODUCTION}

In the southwestern Atlantic, studies on larvae of Crustacea Decapoda have only addressed taxonomical and/or biogeographical aspects, and were conducted in the Argentinean continental shelf and slope, between $36^{\circ} \mathrm{S}$ and $55^{\circ} \mathrm{S}$ latitude (e.g., Boschi, 1981; Bacardit, 1986). The available information comes from oceanographic surveys, carried out primarily to evaluate commercial fishery resources (e.g. Angelescu, 1981).

From the zoogeographic perspective, the Fuegian district is unique because of two facts. First, this is the only area where Atlantic and Pacific species mingle. However, this connection is relatively recent, since the current paths of interchange, i.e., the Magellan Strait and the Beagle Channel were covered by glaciers and became marine environments only 9,000 years ago (Rabassa et al., 1986). Second, despite increasing isolation leading to an independent evolution of South American and Antarctic faunas, exchange of marine species between these two areas remains more intense than between other southern continents. Furthermore, Anomura and Brachyura decapods are virtually absent from the Antarctic benthos (Arntz et al.,
1994). Notwithstanding the potential ability of the planktonic larvae to spread out from the Magellanic province to Antarctica, the reasons for their absence constitute a scientific challenge.

This article represents the first contribution on the seasonal distribution, abundance and duration of the Anomuran and Brachyuran larval stages in the plankton of the Beagle Channel, Argentina, on the basis of a fortnightly sampling programme. Furthermore, I provide a key for the identification of zoeal stages of brachyuran and anomuran crabs.

\section{MATERIAL AND METHODS}

\section{Studied area}

The studied area of the Beagle Channel is located south of the city of Ushuaia and includes Bahía Ushuaia, the surrounding waters of the Bridges Islands, and Bahía Golondrina (Fig. 1). The Channel has an irregular sea-bottom carved by glaciers (Rabassa et al., 1986), which probably provides abundant microhabitats and shelters for the benthic organisms. The temperature at $25 \mathrm{~m}$ depth varies seasonally between $5.4^{\circ} \mathrm{C}$ in August and $9.8^{\circ} \mathrm{C}$ in

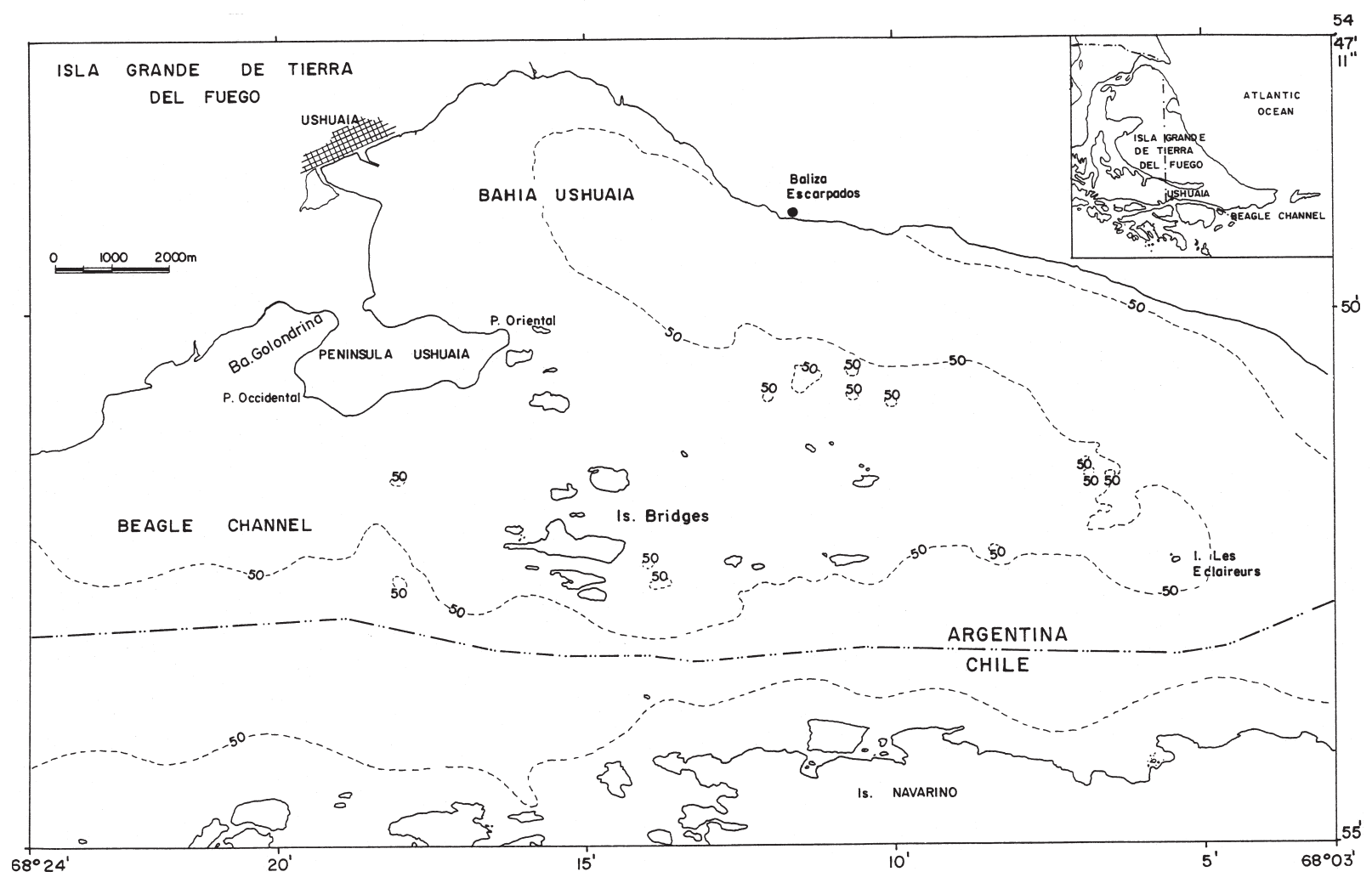

FIG. 1. - Location of sampling. The dashed line indicates the $50 \mathrm{~m}$ isobath . 
March, while the salinity at $25 \mathrm{~m}$ depth varies between and $27.0 \mathrm{~g} \mathrm{l}^{-1}$ in December and $31.2 \mathrm{~g} \mathrm{l}^{-1}$ in November (annual average salinity \pm 1 SD at $25 \mathrm{~m}$ $=29.4 \pm 1.1 \mathrm{~g} \mathrm{l}^{-1}$, own unpublished data). In the area of Bahía Golondrina and Bridges Islands, permanent currents are mainly from the southwest at a maximum of 2.6 and $15.6 \mathrm{~cm} \mathrm{~s}^{-1}$ respectively (Balestrini et al., 1990). In Bahía Ushuaia, a permanent current gyre moves westwards along the northern coast of the bay at $2.0 \mathrm{~cm} \mathrm{~s}^{-1}$, and then progresses to the southeast along the southern coast at $16.3 \mathrm{~cm} \mathrm{~s}^{-1}$.

\section{Sampling procedures}

Between September 1987 and March 1989 a total of 304 samples were taken roughly every two weeks at randomly selected sites, with a Hensen planktonic net of $0.4 \mathrm{~m}$ mouth-diameter with a mouth-reducing cone and a mesh of $200 \mu \mathrm{m}$. Between September 1987 and May 1988, vertical or oblique hauls were performed from the bottom to the sea-surface, so that the entire water column was sampled. Between June 1988 and March 1989, only oblique hauls of 10, 15 or 20 minutes of trawling (mainly 10 minutes) were performed at $3.7 \mathrm{~km} \mathrm{~h}^{-1}$ from the sea-bottom to the surface. Later, tow time was converted into volume of filtered water by means of a calibration curve calculated from TSK-currentmeter data. On average, the volume of filtered water was $4.7 \mathrm{~m}^{3}$ haul $^{-1}$ (range: 1.1-6.7 $\mathrm{m}^{3}$ haul $^{-1}$ ). I am confident that estimations of densities were comparable since the filtration efficiency was very similar among all samples, e.g., trawling speed was precisely controlled and net clogging never occurred. Only hauls done after June 1988 were considered as quantitative, and only for these, density of larvae is presented.

Each sample was immediately fixed and preserved in $4 \%$ buffered formalin in sea-water. For each sample, all Anomura and Brachyura larvae were determined to the lowest taxonomic level and larval stage, and enumerated.

\section{Larval identification}

Three taxa could not be identified to the species level for lack of published descriptions. However, larvae were judged to be Pagurus spp. based on Scelzo (1976). Based on the absence/presence of uropods, Pagurus spp. zoeae were sorted into two stages of development: early (without uropods) and late (with uropods). The "early zoea" category probably includes the first two zoeal stages (c.f. Scelzo and Boschi, 1969). Pinnotherid larvae were morphologically similar among themselves and were supposed to belong to a single taxon herein named Pinnotheridae. However, they did not concur with the available descriptions for Pinnaxodes chilensis $(\mathrm{H}$. Milne Edwards, 1837) (see Schwabe, 1936; Gutierrez Martinez, 1971), which may be present in the Beagle Channel (Boschi, et al., 1992). The taxonomy of Munida subrugosa Henderson, 1847 and $M$. gregaria (Fabricius, 1793) is a subject of controversy. The morphological features that distinguish adults of both species may depend on the habitat where individuals are found, i.e., pelagic $v s$. benthic (Williams, 1973; 1980). Adults of both species are present in the area (Vinuesa, 1977; Rodriguez and Bahamonde, 1986; Boschi et al., 1992; pers. obs.; but see Arntz et al., 1996). Larvae of both species may be present simultaneously in the Beagle Channel (Bacardit, 1986), and they may be morphologically similar (Rayner, 1935). Hence, in the present study I decided to name the larvae Munida spp., although their characters coincided with those of $M$. subrugosa (Roberts, 1973).

\section{RESULTS}

A total of 304 plankton samples were obtained over the 18 months of sampling. Samples from depths shallower than $60 \mathrm{~m}$ represented $85 \%$ of the total number. Twenty-two samples were taken in Bahía Golondrina, 98 in Bahía Ushuaia (between Punta Oriental and Baliza Escarpados), and 184 at the Bridges Islands (Fig. 1). Of the 14 species of Anomura and Brachyura recorded for the Beagle Channel (c.f. Arntz et al., 1996), at least 8 occurred in my samples. The following is a key for the identification of larvae expected to be found in the plankton samples of the Beagle Channel. This key is provided with the bibliographical references, in which the reader may find the original descriptions of larvae.

\section{Key for identification of Anomura and Brachyura zoeae of the Beagle Channel}

1. Dorsal spine on carapace.............. 2

- No dorsal spines on carapace .........6 6

2. No lateral spines on carapace ........... 3

- One pair of lateral spines on carapace .....4

3. One spine external to telson furca, rostral spine shorter than dorsal spine. .............. 
.... . Libidoclaea granaria Milne Edwards and

Lucas, 1842 (see Fagetti, 1969)

- No spines external to telson furca, rostral spine as long as dorsal spine ................ ... . Acanthocyclus albatrossis Rathbun, 1898

(see Campodonico and Guzmán, 1973)

4. Lateral spines on the posterior margin of the carapace, directed postero-ventrally, as long as the rostral spine; last segment of pleon with lateral expansions; telson wide at base ....... .................. Pinnotheridae

- Lateral spines at the mid-carapace, directed laterally, extending slightly past the margin of the carapace; telson narrow at base........ 5

5. Three spines external to telson furca ......... . . . . . . . Eurypodius latreillii Guérin, 1828

(see Bacardit, 1986)
- No spines external to telson furca .......... ........ Peltarion spinosulum (White, 1843)

(see Iorio, 1983)

6. Carapace globose with posterior projection covering one or two pleon somites, frontal spine directed ventrally, telson as typical furca...... ...... Halicarcinus planatus (Fabricius, 1775)

(see Boschi et al., 1969)

- Carapace oblong, frontal spine directed anteriorly, two posterior-lateral processes or spines; telson flat or concave ................ 7

7. Rostrum wider at base, with serrations at tips; telson notably concave..........Munida spp. (see Roberts, 1973)

- Rostrum bare; telson flat or slightly concave . 8

8. Posterior carapace spines small. Telson slightly flat; 6 to 8 pairs of spinulose processes.......
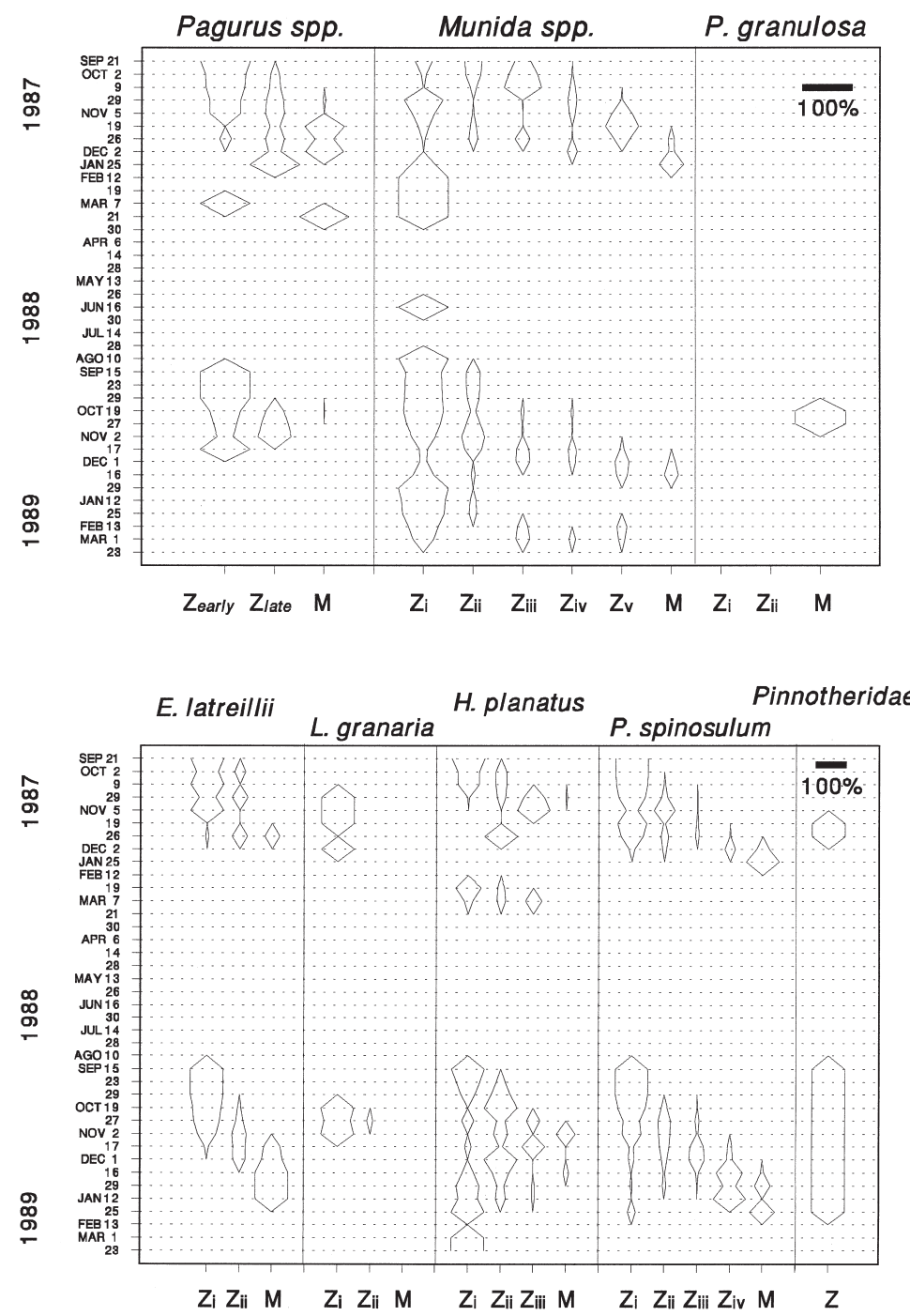

FIG. 2. - Percentage occurrence of larval stages of the anomuran (above) and brachyuran (below) larvae in the Beagle Channel, Argentina. The total of larvae of a given species on a given date of sampling represents $100 \%$. References: Z: zoea; M: megalopa. 

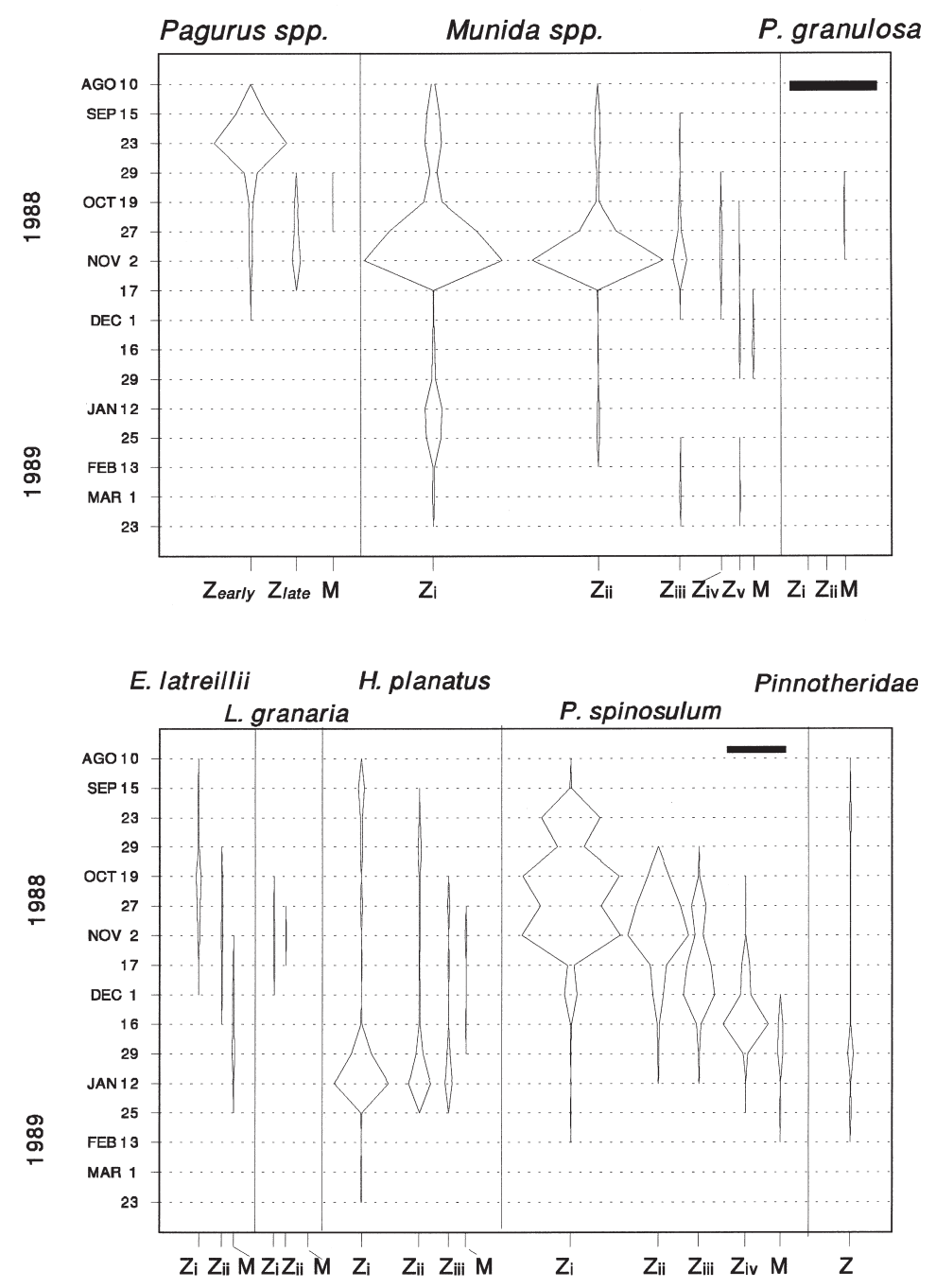

FIG. 3. - Average density of larval stages of the anomuran (above) and brachyuran (below) larvae in the Beagle Channel, Argentina. References: Z: zoea; M: megalopa. The scale bar represents 100 individuals $\cdot 10 \mathrm{~m}^{-3}$.

Pagurus spp. (see Scelzo, 1976)

- Posterior carapace spines prominent. Telson concave with 9 to 11 pairs of spinulose processes. Small spines on abdominal somites . . . . . . . 9

9. Posterior carapace spines wider and robust; dorsal spines on abdominal somites more developed; uropods in zoeae II and III ........ ............ Lithodes santolla (Molina, 1782)

(see Campodonico, 1971)

- Posterior carapace spines and dorsal spines on abdominal somites less developed; no uropods . ......Paralomis granulosa (Jacquinot, 1847) (see Campodonico and Guzmán, 1981)

\section{Seasonal Distribution}

In the Beagle Channel, Anomura and Brachyura larvae exhibited a marked seasonal pattern of abun- dance, and occur mainly in the spring and summer (Fig. 2). In 1987, eggs of the most common species had already hatched, when sampling was initiated in September 21. By the end of March 1988, no larvae were found in the Beagle Channel. In 1988, some zoeae I of Munida spp. appeared in June at a density of 0.2 individuals $\cdot 10 \mathrm{~m}^{-3}$, but larvae of other species were captured only starting in mid-September.

In terms of larval density, 4 of the 8 Anomura and Brachyura taxa together represented $97 \%$ of the total number of larvae collected in the 1988-1989 spring-summer (Fig. 3; Table 1). The average density for all species and stages combined was 5.4 larvae - $10 \mathrm{~m}^{-3}$ (range: $0.1-24.5$ larvae $\cdot 10 \mathrm{~m}^{-3}$ ). The maximum density for all species combined was 625 larvae $\cdot 10 \mathrm{~m}^{-3}$ and occurred at the beginning of November 1988 (Fig. 3). Maximum densities for the 
TABLE 1. - Total of larvae collected in 304 hauls between September 1987 and March 1989. The $100 \%$ of percentage frequency refers to the total of larval individuals caught per $1 \mathrm{~m}^{3}$. "Channel" refers to sampling done in the Channel system and West of Beagle and "S Beagle" to sampling done South of Beagle Channel in 1994 (see Gorny et al., 1996). * refers to L. smithii.

\begin{tabular}{|c|c|c|c|c|}
\hline \multirow[t]{2}{*}{ Taxa } & \multirow[t]{2}{*}{$\begin{array}{l}\text { Total of } \\
\text { larvae } \\
\text { collected }\end{array}$} & \multirow[t]{2}{*}{$\begin{array}{l}\text { Percentage } \\
\text { frequency } \\
\left(\mathrm{N} \cdot 10 \mathrm{~m}^{-3}\right)\end{array}$} & \multicolumn{2}{|c|}{$\begin{array}{c}\text { Percentage frequency } \\
\text { of adults } \\
\text { (Gorny et al. 1996) }\end{array}$} \\
\hline & & & Channel & S Beagle \\
\hline Peltarion spinosulum & 4946 & 52 & 62 & 8 \\
\hline Munida spp. & 3112 & 27 & 2 & 84 \\
\hline Halicarcinus planatus & 764 & 11 & - & $<1$ \\
\hline Pagurus spp. & 1131 & 7 & 17 & 5 \\
\hline Eurypodius latreillii & 191 & 2 & 16 & 5 \\
\hline Pinnotheridae & 78 & 1 & - & $<1$ \\
\hline Libidoclaea granaria & 17 & 0.1 & $5^{*}$ & - \\
\hline Lithodidae & 5 & $<0.1$ & - & $<1$ \\
\hline Total & 10,244 & & & \\
\hline
\end{tabular}

sampling period for larvae of all stages of Munida spp., Peltarion spinosulum, Halicarcinus planatus, and Pagurus spp. were 312, 288, 143, and 79 individuals $\cdot 10 \mathrm{~m}^{-3}$ respectively. Larvae of all stages of Pinnotheridae, Eurypodius latreillii, Libidoclaea granaria and Paralomis granulosa were about an order of magnitude less abundant, with maximum densities of $9.9,9.5,1.8$ and 0.7 individuals $\cdot 10 \mathrm{~m}^{-3}$ respectively.

All but two taxa of Brachyura and Anomura hatch once a year in early spring, since complete larval cohorts were detected (Figs. 2 and 3). In summer 1987, only zoeae I of Munida spp. were caught, while in summer 1989 all zoeal stages were found. The spring 1988 cohort of Munida spp. was about an order of magnitude more abundant than the summer 1989 cohort (Fig. 3). Two cohorts of Halicarcinus planatus were detected: the first in spring and the other in summer (Fig. 2), and the summer cohort was at least one order of magnitude more abundant than the spring cohort (Fig. 3). The occurrence of Pagurus spp. larvae in the summer 1988 was occasional, since only one larva was caught in each of two hauls (Fig. 2).

\section{DISCUSSION}

In the Beagle Channel the time of larval hatching of Brachyura and Anomura taxa is clearly seasonal. Larvae occur at the beginning of the spring and the hatching frequency is annual, as occurs in the Argentinean continental slope south of $40^{\circ} \mathrm{S}$ (Bac- ardit, 1986; Boschi, 1989). The exceptions to the annual hatching pattern are Halicarcinus planatus and Munida spp., which clearly exhibited two cohorts. Similarly, in the Kerguelen Islands $\left(70^{\circ} \mathrm{E}\right.$; $50^{\circ} \mathrm{S}$ ) larvae of $H$. planatus occur during NovemberMarch, but the seasonality of larval stages was not reported (Richer de Forges, 1977). By contrast, in the Argentinean continental shelf, $H$. planatus larvae occur only during spring (Bacardit, 1986). My results suggest that in the Beagle Channel larval development of Munida spp. is variable: the spring cohort is more abundant, develops normally and reaches the megalopal stage, while the summer cohort may fail to fully develop, as in the case near the Islas Malvinas (Falklands) (Rayner, 1935; Bacardit, 1986). Similarly, in the southwestern Pacific, $M$. gregaria zoeae I that emerge late in the season may not develop further (Zeldis, 1985). In the Beagle Channel, it is essential to resolve the differential pattern of distribution and reproductive cycles of Munida subrugosa and M. gregaria before positing any hypothesis about larval seasonality.

The percentage occurrence of the Anomura and Brachyura larvae showed in this study coincides roughly with the percentage occurrence of adults. Peltarion spinosulum is the dominant species since frequencies of occurrence of both larvae and adults are high (Table 1). Larvae of Munida spp. and Halicarcinus planatus represented together $38 \%$ of total larvae collected, although benthic stages of these species were not well represented in the 1994 samples from the Channel system and Beagle Channel (Gorny et al., 1996). This was probably because $H$. planatus is more abundant in the inter- and subtidal environments, which were not sampled in 1994. Although Munida subrugosa was very scarce in the Channel System during the 1994 sampling (Gorny et $a l .$, 1996), we have recently recorded that in spring and summer and in terms of numbers, $M$. subrugosa is the most important species in shallow waters $(<50$ $m$ depth) of the Beagle Channel near Ushuaia (unpubl. results). Its seasonal abundance is also reflected in the diet of the omnivorous fish Eleginops maclovinus (Valenciennes, 1830) (see Isla and San Román, 1995). Therefore, the relative abundance of larvae of this species agrees with the relative abundance of benthic stages.

On average, decapod larvae were less abundant in the Beagle Channel than in the Antarctic. Average density in the Beagle Channel was about one order of magnitude lower than the average density of 41 individuals $\cdot 10 \mathrm{~m}^{-3}$ reported for the 4 Antarctic 
Caridea (Piatkowski, 1987). However, maximum densities of 600 larvae $\cdot 10 \mathrm{~m}^{-3}$ of the Antarctic shrimp Notocrangon antarcticus (Pfeffer, 1887) are comparable with maximum average densities found in November 1988 in the Beagle Channel. Since Caridea larvae were not considered in the present study, no further comparison is feasible.

Certain larvae were difficult to identify to the specific level because larval development of some species is not known and/or the presence of certain species was only recently reported (c.f. Arntz and Gorny, 1996). Three species of Pagurus may occur in the Beagle Channel, and larvae caught during this study probably belong to any or all of them. Pagurus comptus White, 1847 is the most abundant species, while P. gaudichaudii $\mathrm{H}$. Milne Edwards, 1836 is a scarce one (Gorny et al., 1996; pers. obs.). Pagurus forceps may also occur in the Beagle Channel, since it was reported off the Staten Island and south of the Navarino Island (Yaldwin, 1958). Larvae classified as Libidoclaea granaria agreed with the description presented by Fagetti (1969). However, L. smithii (Miers, 1886) also occurs in the Channel system and Beagle Channel (Gorny et al., 1996). Its larval development is unknown, and morphological differences between larvae of the two species may be subtle. Therefore, a certain degree of uncertainty may be associated with the classification of Libidoclaea spp. larvae. Pinnotheridae species probably present in the Beagle Channel are Pinnixa valdiviensis Rathbun, 1907, Pinnaxodes chilensis, and Pinnotherelia laevigata Milne Edwards and Lucas, 1843 (see Boschi et al., 1992; Gorny et al., 1996). Larvae collected during the present study did not agree with the description of $P$. chilensis larvae (c.f. Gutierrez-Martinez, 1971), and the presence in the Beagle Channel of P. laevigata has not yet been confirmed. Hence, pinnotherid larvae collected during the present study probably belonged to Pinnixa valdiviensis. Moreover, despite their absence in an extensive sampling (Fenucci, 1975), the presence of P. valdiviensis south of the Beagle Channel was confirmed by Gorny et al. (1996), and my results support their occurrence in the Beagle Channel.

The absence of certain larval stages or larvae of certain species from the plankton probably indicates their differential distribution within the Beagle Channel. During this study, Libidoclaea granaria megalopae were not caught and zoeae II were caught only once during spring 1988 (Fig. 3). In the Beagle Channel, benthic stages of Libidoclaea spp. occur in waters $>200 \mathrm{~m}$ deep (pers. obs.; Gorny et al., 1996). As in other majid species, the bathymetric distribution of larvae may change with larval development, i.e., late stages close to settlement may have a depth-distribution similar to the benthic stages (e.g. Kon, 1980). Therefore, the occurrence of Libidoclaea spp. larvae may have been misjudged, since my sampling was conducted mainly in waters shallower than $60 \mathrm{~m}$ depth. Larvae of Acanthocyclus albatrossis were absent from my samples, although benthic stages occur at high densities $(\sim 50$ individuals $\left.\cdot \mathrm{m}^{-2}\right)$ in some mussel beds in the eastern Beagle Channel $\left(67^{\circ} 18^{\prime} \mathrm{W}\right.$; 54 $4^{\circ} 53^{\prime} \mathrm{S}$; pers. obs.). Hence, I suggest that their absence near Ushuaia may be due to the dominant eastwards currents (Balestrini et al., 1998), which prevent larvae from entering the western sector of the Beagle Channel through the Paso MacInlay.

Some $P$. granulosa larvae were found in October 1988 and none of $L$. santolla were caught. Larval absence markedly contrasts with the abundance of benthic stages in shallow waters $<50 \mathrm{~m}$ deep, which have supported fishery since the 1960s. However, the $7 \%$ of ovigerous females of L. santolla reported for 1988 (Lovrich, 1997) may partially explain the absence of larvae from plankton samples. Lithodid larvae also were missing from plankton samplings conducted previously in the Beagle Channel and in the Argentinean continental shelf and slope (Boschi et al., 1984; Bacardit, 1986), where about $90 \%$ of females were ovigerous (Vinuesa and Lovrich, unpubl. results). Similarly, in the eastern Bering Sea, L. aequispinus Benedict, 1894 larvae were absent from plankton samples since they are more benthic than planktonic in habit (Jewett et al., 1985), while larvae of its sympatric Paralithodes camtschaticus (Tilesius, 1815) and P. platypus (Brandt, 1850) were present (Somerton and Otto, 1986). In laboratory cultures, larvae of P. granulosa, L. santolla, L. aequispinus and L. maja Linnaeus, 1758 have a marked demersal behavior (Vinuesa et al., 1985; 1989; Shirley and Zhou, 1997, K. Anger, pers. comm.). Hence, I hypothesize that in the Beagle Channel lithodid larvae have benthic or epibenthic habits which make these larvae difficult to obtain by means of conventional methods of plankton sampling.

\section{ACKNOWLEDGEMENTS}

I am grateful to Claudio Mattenet, Pedro Medina and Carlos Cantú for their assistance in the field. This project was funded by the Consejo Nacional de Inves- 
tigaciones Científicas y Técnicas (CONICET) by PID $N^{\circ}$ 309900/85 granted to Dr. J. H. Vinuesa. Drs. D. Boltovskoy, E. Boschi, M. Gorny, B. Sainte-Marie, J.H. Vinuesa, and H. Zaixso provided helpful comments on different versions of the manuscript. The author is a Researcher of the Consejo Nacional de Investigaciones Científicas y Técnicas (CONICET).

\section{REFERENCES}

Angelescu, V. - 1981. Campañas de investigación pesquera realizadas en el Mar Argentino por los B/I "Shinkai Maru" y "Walther Herwig" y el B/P "Marburg", años 1978 y 1979. Resultados de la parte argentina. Contrib. INIDEP, 383: 1-339.

Arntz, W. and M. Gorny. - 1996. Cruise report of the Joint ChileanGerman-Italian Magellan "Victor Hensen" Campaign in 1994. Ber. Polarforsch., 190: 1-113.

Arntz, W.E., T. Brey and V.A. Gallardo. - 1994. Antarctic zoobenthos. Oceanog. Mar. Biol.: Ann. Rev., 32: 241-304.

Arntz, W.E., M. Gorny, I.S. Wehrtmann, M. Lardies and R. Soto. 1996. Crustacea Decapoda: Summary report. In: W.E. Arntz and M. Gorny (eds): Cruise report of the Joint Chilean-German-Italian Magellan "Victor Hensen" Campaign in 1994. Ber. Polarforsch., 190: 57-60.

Bacardit, R. - 1986. Larvas de Crustacea Decapoda del mar patagónico argentino, incluyendo el talud continental, adyacencias a la Tierra del Fuego e Islas Malvinas. Aspectos morfológicos, ecológicos y filogenéticos. Ph. D. thesis, Univ. Buenos Aires.

Balestrini, C.F., J.H. Vinuesa, G.A. Lovrich, C.E. Mattenet, C.E. Cantú and P.V. Medina. - 1990. Estudio De corrientes en los alrededores de la Península Ushuaia. Contrib. Cient. CADIC, 10:1-33.

Balestrini, C.F., G. Manzella and G.A. Lovrich. - 1998. Simulación de corrientes en el Canal Beagle y Bahía Ushuaia, mediante un modelo bidimensional. Serv. Hidrogr. Naval. Informes Técn., 98: $1-58$.

Boschi, E.E. - 1981. Larvas de Crustacea Decapoda. In: D. Boltovskoy (ed.): Atlas del zooplancton del Atlantico sudoccidental y métodos de trabajo con el zooplancton marino. pp. 699-758. Publ. Espec. INIDEP, Mar del Plata.

Boschi, E.E., D.A. Bertuche and J.G. Wyngaard. - 1984. Estudio biológico pesquero de la centolla (Lithodes antarcticus) del Canal Beagle, Tierra del Fuego, Argentina. Contrib. INIDEP, 441: 1-72.

Boschi, E.E., C.E. Fischbach and M.I. Iorio. - 1992. Catálogo ilustrado de los crustáceos estomatópodos y decápodos marinos de Argentina. Frente Marítimo, 10 A: 7-94.

Boschi, E.E., M.A. Scelzo and B. Goldstein. - 1969. Desarrollo larval del cangrejo Halicarcinus planatus (Fabricius) (Crustacea, Decapoda, Hymenosomidae), en el laboratorio, con observaciones sobre la distribución de la especie. Bull. Mar. Sci., 19(1): 225-242.

Campodonico, I. - 1971. Desarrollo larval de la centolla Lithodes antarcticus Jacquinot en condiciones de laboratorio. Ans. Inst. Pat., 2: 181-190.

Campodonico, I. and L. Guzmán. - 1973. Contribución a la biología de Acanthocyclus albatrossis Rathbun 1898. Ans. Inst. Pat., 4: 374-416.

Campodonico, I. and L. Guzmán. - 1981. Larval development of Paralomis granulosa under laboratory conditions. Crustaceana, 40(3): 278-285.

Fagetti, E. - 1969. The larval development of the spider crab Libidoclaea granaria $\mathrm{H}$. Milne Edwards and Lucas under laboratory conditions (Decapoda Brachyura; Majidae, Pisinae). Crustaceana, 17: 131-140.

Fenucci, J.L. - 1975. Los cangrejos de la familia Pinnotheridae del litoral argentino (Crustacea, Decapoda, Brachyura). Physis Secc. A, 34 (88): 165-184.

Gorny, M., W.E. Arntz and R. Soto. - 1996. Crustacea Decapoda: Report on the anomuran and brachyuran crabs. In: W.E. Arntz and M. Gorny.(eds): Cruise report of the Joint Chilean-German-Italian Magellan "Victor Hensen" Campaign in 1994. Ber. Polarforsch., 190: 60-63.

Gutierrez-Martinez, J. - 1971. Notas biológicas sobre Pinnaxodes chilensis (M. Edwards) y descripción de su primera Zoea (Crustacea, Decapoda, Anomura). Mus. Nac. Hist. Nat. Santiago (Chile), 176: 3-10.

Iorio, I. - 1983. Estadios larvales del cangrejo Peltarion spinosulum (White) (Crustacea, Decapoda, Brachyura, Atelecyclidae). Physis Secc. A, 41 (101): 143-156.

Isla, M.S. and N.A. San Román. - 1995. Alimentación de Eleginops maclovinus (Pisces, Notothenidae) en el Canal Beagle, Argentina. Nat. Patag. Cs. Biol., 3: 107-127.

Jewett, S.C., N.A. Sloan and D.A. Somerton. - 1985. Size at sexual maturity and fecundity of the fjord-dwelling golden king crab Lithodes aequispina Benedict from northern British Columbia. J. Crust. Biol., 5: 377-385.

Kon, T. - 1980. Studies on the life history of the zuwai crab, Chionoecetes opilio (O. Fabricius). Spec. Publ. Sado Mar. Biol. Stn., Niigata Univ. Ser., 2: 64 p. (in Japanese). Can. Transl. Fish. Aquat. Sci., 5634: 1-125.

Lovrich, G.A. - 1997. La pesquería mixta de centollas Lithodes santolla y Paralomis granulosa (Anomura: Lithodidae) en Tierra del Fuego, Argentina. Invest. Mar., Valparaíso, 25: 41-57.

Piatkowski, U. - 1987. Zoogeographische Untersuchungen und Gemeinschaftsanalysen an antarktischem Makroplankton. Ber. Polarforsch., 34: 1-150.

Rabassa, J.O., C. Heusser and R. Stuckenrath. - 1986. New data on Holocene sea transgression in the Beagle Channel: Tierra del Fuego, Argentina. Quat. South Amer. Antarct. Peninsula, 4: 291-309.

Rayner, J.W. - 1935. The Falkland species of the crustacean genus Munida. Discovery Rep., 10: 209-245.

Richer de Forges, B. - 1977. Etude du crabe des Iles Kerguelen Halicarcinus planatus (Fabricius). CNFRA, 42: 71-133.

Roberts, P.E. - 1973. Larvae of Munida subrugosa (White, 1847), from Perseverance Harbour, Campbell Island. J. Royal Soc. New Zealand, 3(3): 393-408.

Rodriguez, L. and R. Bahamonde. - 1986. Contribución al conocimiento de Munida subrugosa (White, 1847) en la XII Región, Chile. In: P. Arana (ed.): La pesca en Chile, pp. 283296. Universidad Católica de Valparaíso, Valparaíso.

Scelzo, M.A. - 1976. Larvas de los crustáceos decápodos anomuros identificadas en las aguas marinas argentinas. Physis Secc. A, 35(90): 37-45.

Scelzo, M.A. and E.E. Boschi. - 1969. Desarrollo larval del cangrejo ermitaño Pagurus exilis (Benedict) en laboratorio (Crustacea, Anomura, Paguridae). Physis Secc. A, 29 (78): 165-184.

Schwabe, G.H. - 1936. Investigaciones sobre Loxechinus albus Mol. y Pinnotheres chilensis Edw. Bol. Soc. Biol. Concepción (Chile), 10: 125-136.

Shirley, T.C. and S. Zhou. - 1997. Lecithotrophic development of the golden king crab Lithodes aequispinus (Anomura: Lithodidae). J. Crust. Biol., 17(2): 207-216.

Somerton, D.A. and R.S. Otto. - 1986. Distribution and reproductive biology of the golden king crab Lithodes aequispina, in the eastern Bering Sea. Fish. Bull. U.S., 84: 571-584.

Vinuesa, J. H. - 1977. Aportes al conocimiento de los crustáceos decápodos de Tierra del Fuego con algunas observaciones zoogeográficas. Physis Secc. A, 36 (92): 9-19.

Vinuesa, J.H., L. Ferrari and R.J. Lombardo. - 1985. Effects of temperature and salinity on larval development of southern king crab (Lithodes antarcticus). Mar. Biol., 85(1): 83-88

Vinuesa, J.H., G.A. Lovrich and L.I. Comoglio. - 1989. Temperature-salinity effects on the development of false southern King Crab (Paralomis granulosa). Thalassas, 7: 51-56.

Williams, B.G. - 1973. The effect of the environment on the morphology of Munida gregaria (Fabricius). Crustaceana, 24: 197210 .

Williams, B.G. - 1980. The pelagic and benthic phases of postmetamorphic Munida gregaria (Fabricius) (Decapoda, Anomura). J. exp. mar. Biol. Ecol., 42: 125-141.

Yaldwyn, J.C. - 1958. Decapod Crustacea from the subantarctic seal and shag stomachs. Rec. Dom. Mus., 3: 121-127.

Zeldis, J.R. - 1985. Ecology of Munida gregaria (Decapoda, Anomura): distribution and abundance, population dynamics and fisheries. Mar. Ecol. Prog. Ser., 22: 77-99. 